\title{
Hasil Positif Palsu dan Negatif Palsu pada Pemeriksaan Cepat Antibodi SARS CoV-2
}

\author{
Patricia Gita Naully ${ }^{1}$ dan Perdina Nursidika ${ }^{2}$ \\ 1,2Teknologi Laboratorium Medik (D-4), Stikes Jenderal Achmad Yani \\ patriciagitanaully@gmailcom ${ }^{1}$ dan perdina.sensei@gmail.com²
}

\author{
ABSTRAK \\ Diajukan 2 Januari 2021 Diperbaiki 8 Februari 2021 Diterima 19 Februari 2021
}

Latar Belakang: Salah satu cara yang dilakukan Indonesia untuk mengendalikan dan mencegah penularan SARS CoV-2 sebagai penyebab COVID-19 adalah dengan menyediakan kit pemeriksaan cepat anti-SARS CoV-2. Metode pemeriksaan tersebut dapat mengatasi keterbatasan tenaga ahli dan alat laboratorium di Indonesia.

Tujuan: Menentukan hasil pemeriksaan cepat anti-SARS CoV-2 pada masyarakat di Kecamatan Cimahi Tengah.

Metode: Sebanyak 50 orang diambil sebagai sampel penelitian dengan menggunakan teknik quota sampling. Pemeriksaan cepat anti-SARS CoV-2 dilakukan dengan menggunakan imunokromatografi merek Lungene. Sampel penelitian yang reaktif diperiksa kembali dengan metode Quantitative Reverse Transcription Polymerase Chain Reaction (qRT-PCR).

Hasil: Berdasarkan hasil pemeriksaan dengan imunokromatografi, terdapat satu orang $(2 \%)$ anti-

SARS CoV-2 IgM reaktif dan tiga orang (6\%) anti-SARS CoV-2 IgG reaktif. Pemeriksaan dengan qRTPCR menunjukkan hasil yang berbeda. Keempat orang tersebut dinyatakan negatif COVID-19. Selain itu, satu orang $(2 \%)$ yang mendapatkan hasil non-reaktif pada pemeriksaan cepat justru dinyatakan positif terinfeksi SARS CoV-2.

Kesimpulan: Pemeriksaan cepat anti-SARS CoV-2 yang dilakukan di Kecamatan Cimahi Tengah kurang akurat karena terdapat empat $(8 \%)$ hasil positif palsu dan satu (2\%) hasil negatif palsu.

Kata Kunci: COVID-19; Imunokromatografi; SARS CoV-2

\section{ABSTRACT}

Background: One of the ways that Indonesia has taken to control and prevent the transmission of SARS CoV-2 which causes COVID-19 is to provide anti-SARS CoV-2 rapid test kits. This examination method can overcome the limitations of personnel and laboratory equipment in Indonesia.

Objective: Determine the results of anti-SARS CoV-2 rapid test in the community of Central Cimahi Subdistrict.

Method: Fifty people as the research samples of were taken using a quota sampling technique. The anti-SARS $\mathrm{CoV}-2$ rapid test was conducted using immunochromatography brand Lungene. Reactive samples were reexamined by a Quantitative Reverse Transcription Polymerase Chain Reaction ( $q$ RT-PCR) method.

Results: Based on the results of immunomatography examinations, there was one person (2\%) anti-SARS CoV2 IgM reactive and three people (6\%) anti-SARS CoV-2 IgG reactive. Different results were shown by the qRTPCR method. The four people were declared negative for COVID-19. In addition, one person (2\%) who received a non-reactive result in the rapid test was declared positive to be infected with SARS CoV-2.

Conclusion: The anti SARS CoV-2 rapid test conducted in Central Cimahi Subdistrict is not accurate because there are four ( $8 \%$ ) false positive results and one (2\%) false negative result.

Keywords: COVID-19; Immunochromatography; SARS CoV-2 
PENDAHULUAN

Corona Virus Disease 2019 (COVID-19) merupakan sindrom pernapasan akut parah yang disebabkan oleh Severe Acute Respiratory Syndrome Coronavirus 2 (SARS CoV-2) yang ditemukan pertama kali di Cina pada Desember 2019 (Okba et al., 2020; Zhou et al., 2020). Beberapa penelitian menyebutkan bahwa SARS $\mathrm{CoV}-2$ adalah virus corona pada kelelawar yang mengalami mutasi genetik (Rothan \& Byrareddy, 2020; Susilo et al., 2020). Virus tersebut memiliki material genetik berupa RNA dan termasuk ke dalam genus Betacoronavirus (Handayani et al., 2020; Lu et al., 2020; Okba et al., 2020).

Walaupun SARS CoV-2 masih dalam satu kelompok dengan Severe Acute Respiratory Syndrome Coronavirus (SARS $\mathrm{CoV})$ dan Middle East Respiratory Syndrome Coronavirus (MERS $\mathrm{CoV}$ ), tingkat penyebaran SARS CoV-2 jauh lebih tinggi dibandingkan kedua virus tersebut (Handayani et al., 2020; Okba et al., 2020). COVID-19 sudah menjadi pandemi karena jumlah kasusnya meningkat sangat pesat dan sudah menyebar luas di seluruh dunia (Shibata et al., 2020).

SARS CoV-2 dapat ditransmisikan melalui droplet yang dikeluarkan seseorang ketika orang tersebut batuk atau bersin (Susilo et al., 2020; van Doremalen et al., 2020). Orang yang terinfeksi SARS CoV-2 umumnya menunjukkan gejala klinis, seperti demam dengan suhu sekitar $38,1-39^{\circ} \mathrm{C}$, batuk, bersin, sesak napas, nyeri tenggorokan, sakit kepala, atau kelelahan, tetapi ada pula yang tidak menunjukkan gejala (Huang et al., 2020; Susilo et al., 2020). Rata-rata angka kematian global yang disebabkan oleh SARS CoV-2 adalah sekitar 3,79\% (WHO, 2020).

Sampai saat ini, antivirus untuk menghambat replikasi SARS CoV-2 belum ditemukan (Handayani et al., 2020; Susilo et al., 2020). Walaupun vaksin untuk COVID-19 sudah diproduksi, jumlahnya belum mencukupi kebutuhan nasional.
Oleh karena itu, untuk mengendalikan dan mencegah penularan COVID-19 dibutuhkan metode pemeriksaan yang akurat. Orang yang mengetahui bahwa dirinya sudah terinfeksi dapat melakukan isolasi mandiri sehingga tidak menyebarkan virus SARS CoV-2.

Saat ini, metode deteksi yang dijadikan standar emas adalah Real Time Reverse Transcription Polymerase Chain Reaction (rRT-PCR) atau disebut juga Quantitative Reverse Transcription Polymerase Chain Reaction (qRT-PCR). Metode deteksi ini dilakukan dengan menggunakan spesimen yang diperoleh dari saluran pernapasan atas atau bawah pasien (Huang et al., 2020; Lu et al., 2020).

Terdapat beberapa keterbatasan dari metode qRT-PCR, yaitu membutuhkan waktu yang relatif lama, alat laboratorium yang khusus, tenaga ahli, dan biaya yang relatif mahal (Choe et al., 2020). Untuk mengatasi keterbatasan tersebut, metode berbasis serologi telah dikembangkan, yaitu imunokromatografi. Pemeriksaan ini disebut juga rapid test (pemeriksaan cepat) karena mudah dikerjakan dan hasil pemeriksaan didapatkan dalam waktu kurang lebih 15 menit.

Penyakit COVID-19 mulai menyebar di Indonesia sejak Maret 2020 (Handayani et al., 2020; Susilo et al., 2020). Berdasarkan data Kementerian Kesehatan RI (2020), hingga 5 Desember 2020 terdapat 569.707 orang terkonfirmasi positif COVID-19, 17.589 orang di antaranya meninggal, 470.449 orang dinyatakan sembuh, dan 81.669 orang masih dalam perawatan. Walaupun angka kematian akibat penyakit tersebut menurun, jumlah kasus positif di Indonesia cenderung meningkat setiap harinya.

Menanggapi hal tersebut, Indonesia sudah menerapkan pembatasan sosial berskala besar (PSBB) dan mengimpor kit pemeriksaan cepat dalam jumlah banyak. Pada awal terjadinya kasus COVID-19, masih banyak laboratorium kesehatan di Indonesia yang tidak memiliki fasilitas 
untuk pemeriksaan qRT-PCR atau tidak memiliki media pengambilan spesimen, seperti swab dan Virus Transport Media (VTM). Oleh sebab itu, Direktorat Jenderal Pencegahan dan Pengendalian Penyakit Kementerian Kesehatan Republik Indonesia mengijinkan dilakukannya pemeriksaan cepat anti-SARS CoV-2 pada masyarakat dengan spesimen berupa darah (Kemenkes RI, 2020b).

Jawa Barat merupakan provinsi di Indonesia yang menduduki posisi ke-3 dengan jumlah kasus COVID-19 terbanyak, yaitu 57.885 kasus. Salah satu kota di Jawa Barat yang mengalami peningkatan kasus COVID-19 tertinggi adalah Cimahi (Pemda Cimahi, 2020).

Cimahi merupakan kota yang cukup sering diberitakan sebagai zona merah COVID-19. Kota tersebut memiliki wilayah yang kecil, tetapi hingga 30 Desember 2020 terdapat 2.046 orang yang terinfeksi SARS CoV-2, dengan 1.416 orang sembuh, 57 orang meninggal, dan masih terdapat 573 kasus aktif (Pemda Cimahi, 2020).

Salah satu rumah sakit rujukan pemeriksaan COVID-19 di kota tersebut terletak di Kecamatan Cimahi Tengah. Oleh karena itu, tujuan penelitian ini adalah mengetahui hasil pemeriksaan cepat anti-SARS CoV-2 pada masyarakat di Kecamatan Cimahi Tengah dengan menggunakan metode imunokromatografi.

\section{METODE}

Populasi pada penelitian ini adalah seluruh masyarakat di Kecamatan Cimahi Tengah, Kota Cimahi, Indonesia. Sampel dalam penelitian ini berjumlah 50 orang yang diambil dengan teknik quota sampling. Semua sampel penelitian bertempat tinggal di Kecamatan Cimahi Tengah dan bersedia untuk mengikuti rangkaian pemeriksaan cepat anti-SARS CoV-2.

Pengumpulan data diawali dengan pengukuran suhu tubuh pada sampel penelitian. Selanjutnya, sampel penelitian diminta untuk membaca lembar informasi, mengisi kuesioner, dan menandatangani informed consent. Lembar informasi berisi penjelasan mengenai latar belakang penelitian, tujuan, manfaat, risiko pemeriksaan dan penanganannya, kompensasi bagi sampel penelitian, serta kerahasiaan data penelitian.

Kuesioner yang digunakan berisi 15 pertanyaan terkait identitas, gejala klinis, riwayat penyakit, kebiasaan dalam penggunaan masker, dan aktivitas yang dilakukan sampel penelitian selama 14 hari. Setelah mengisi informed consent, dilakukan pengambilan darah vena sebanyak 3 cc dengan menggunakan spuit. Darah tersebut langsung dimasukkan ke dalam tabung vakum berisi antikoagulan EDTA yang sudah diberi identitas.

Rangkaian proses tersebut dilakukan di ruang terbuka guna mencegah penyebaran COVID-19. Semua sampel penelitian diwajibkan menggunakan masker. Tim peneliti juga menggunakan masker, sarung tangan, face shield, dan baju hazmat.

Kit imunokromatografi (Lungene) yang digunakan untuk pemeriksaan antiSARS CoV-2 dalam penelitian ini memiliki sensitivitas sebesar 87,01\% (IgM) dan $97,40 \%$ (IgG) serta spesifisitas sebesar 98,89\% (IgM dan IgG). Sampel penelitian yang mendapatkan hasil reaktif pada pemeriksaan tersebut dirujuk untuk melakukan pemeriksaan konfirmasi dengan menggunakan metode qRT-PCR. Pemeriksaan tersebut dilakukan oleh pihak puskesmas kota Cimahi.

Limbah pada penelitian ini dimusnahkan dengan cara insenerasi. Seluruh rangkaian pemeriksaan ini sudah mendapatkan persetujuan dari Satuan Petugas (Satgas) Penanganan dan Pencegahan COVID-19 serta Komisi Etik Penelitian Kesehatan Sekolah Tinggi Ilmu Kesehatan Jenderal Achmad Yani dengan Nomor 002/KEPK/XI/2020.

Data dalam penelitian ini diolah 
Hasil Positif Palsu dan Negatif Palsu pada Pemeriksaan Cepat...

secara statistik deskriptif dengan menghitung frekuensi data dan menyajikannya dalam bentuk tabel serta grafik. Hal tersebut dilakukan untuk membandingkan hasil pemeriksaan COVID-19 dengan menggunakan metode imunokromatografi dan qRT-PCR.

\section{HASIL DAN PEMBAHASAN}

Pada penelitian ini telah dilakukan pemeriksaan cepat anti-SARS CoV-2 terhadap 50 orang sampel penelitian. Sampel tersebut terdiri dari $62 \%$ perempuan dan 38\% laki-laki dengan rentang umur 23-62 tahun (Tabel 1). Hasil pemeriksaan suhu tubuh pada saat itu menunjukkan bahwa semua sampel penelitian memiliki suhu tubuh normal (36-37oC).

Hasil pemeriksaan cepat anti-SARS CoV-2 menunjukkan adanya satu orang anti- SARS CoV-2 IgM reaktif dan tiga orang anti-SARS CoV-2 IgG reaktif (Gambar 1). Pada spesimen yang reaktif telah dilakukan pemeriksaan ulang (duplo) dengan kit imunokromatografi yang sama. Hasil pemeriksaan ini tidak didukung dengan gejala klinis yang dialami sampel penelitian.

Berdasarkan hasil kuesioner, tiga orang sampel penelitian yang dinyatakan reaktif pada pemeriksaan anti SARS CoV2 tidak mengalami demam dan gangguan pernapasan seperti batuk, pilek, atau sesak nafas (Tabel 1). Hanya ada satu orang sampel yang mengaku pernah mengalami demam seminggu sebelum dilakukannya pemeriksaan. Seluruh sampel yang dinyatakan reaktif tidak pernah kontak dengan penderita COVID19, tidak melakukan perjalanan ke luar kota selama 14 hari terakhir, selalu menggunakan masker kain, dan tidak pernah melakukan aktivitas di tempat ramai.

Walaupun demikian, sesuai dengan tata laksana pemeriksaan COVID-19 di Indonesia, keempat orang tersebut dirujuk untuk melakukan pemeriksaan konfirmasi dengan menggunakan metode qRT-PCR. Hasil pemeriksaan qRT-PCR menunjukkan bahwa keempat orang tersebut tidak terinfeksi SARS CoV-2. Hal ini membuktikan bahwa hasil yang didapatkan pada pemeriksaan cepat antiSARS CoV-2 adalah positif palsu.

Dua hari setelah dilakukannya pemeriksaan cepat anti-SARS CoV-2, terdapat satu orang sampel penelitian yang mengalami demam tinggi $(38,7 \mathrm{oC})$. Orang tersebut langsung melakukan pemeriksaan menggunakan qRT-PCR dan dinyatakan positif terinfeksi SARS CoV-2.

Hal ini menunjukkan kemungkinan adanya hasil negatif palsu pada pemeriksaan cepat anti-SARS CoV-2 yang telah dilakukan, tetapi penelusuran untuk mengetahui waktu paparan perlu dilakukan. Karena hasil pemeriksaan cepat pada penelitian ini menunjukkan banyak positif palsu dan negatif palsu, analisis dan pembahasan karakteristik sampel yang berpengaruh terhadap infeksi SARS CoV-2 tidak dapat dilakukan.

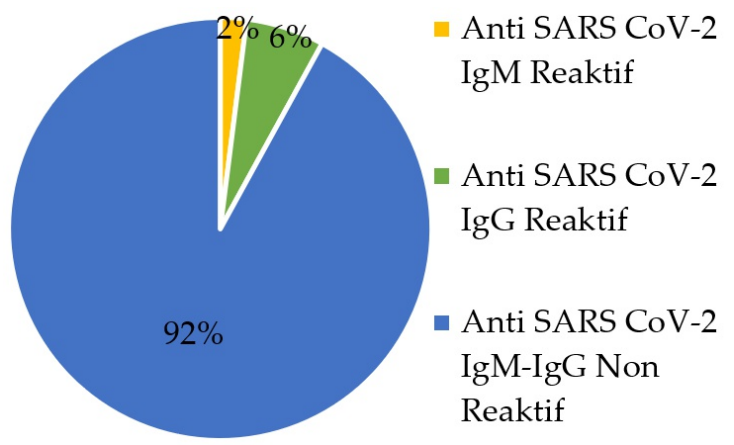

Gambar 1. Hasil Pemeriksaan Cepat Anti SARS CoV-2 di Kecamatan Cimahi Tengah 
Hasil Positif Palsu dan Negatif Palsu pada Pemeriksaan Cepat...

Tabel 1. Karakteristik Sampel Penelitian Pemeriksaan Cepat Anti SARS CoV-2 di Kecamatan Cimahi Tengah

\begin{tabular}{|c|c|c|c|c|}
\hline No & Variabel & Total & IgM* Reaktif n (\%) & IgG* Reaktif n (\%) \\
\hline \multirow[t]{3}{*}{1} & Jenis Kelamin & & & \\
\hline & Perempuan & 31 & $0(0 \%)$ & $1(3,22 \%)$ \\
\hline & Laki-laki & 19 & $1(5,26 \%)$ & $2(10,52 \%)$ \\
\hline \multirow[t]{6}{*}{2} & Usia (Tahun) & & & \\
\hline & $21-30$ & 11 & $0(0 \%)$ & $1(9,09 \%)$ \\
\hline & $31-40$ & 19 & $1(5,26 \%)$ & $2(10,52 \%)$ \\
\hline & $41-50$ & 12 & $0(0 \%)$ & $0(0 \%)$ \\
\hline & $51-60$ & 7 & $0(0 \%)$ & $0(0 \%)$ \\
\hline & $61-70$ & 2 & $0(0 \%)$ & $0(0 \%)$ \\
\hline \multirow[t]{3}{*}{3} & Kontak dengan penderita COVID-19 & & & \\
\hline & Ya & 0 & $0(0 \%)$ & $0(0 \%)$ \\
\hline & Tidak & 50 & $1(2 \%)$ & $3(6 \%)$ \\
\hline \multirow[t]{3}{*}{4} & Demam dalam waktu 14 hari terakhir & & & \\
\hline & Ya & 1 & $0(0 \%)$ & $1(100 \%)$ \\
\hline & Tidak & 49 & $1(2,04 \%)$ & $2(4,08 \%)$ \\
\hline \multirow[t]{3}{*}{5} & $\begin{array}{l}\text { Gangguan pernapasan seperti batuk, pilek atau } \\
\text { sesak nafas dalam waktu } 14 \text { hari terakhir }\end{array}$ & & & \\
\hline & Ya & 4 & $0(0 \%)$ & $0(0 \%)$ \\
\hline & Tidak & 36 & $1(2,77 \%)$ & $3(8,33 \%)$ \\
\hline \multirow[t]{3}{*}{6} & $\begin{array}{l}\text { Melakukan perjalanan ke luar kota dalam } \\
\text { waktu } 14 \text { hari terakhir }\end{array}$ & & & \\
\hline & Ya & 8 & $0(0 \%)$ & $1(12,5 \%)$ \\
\hline & Tidak & 42 & $1(2,38 \%)$ & $2(4,76 \%)$ \\
\hline \multirow[t]{4}{*}{7} & $\begin{array}{l}\text { Alat transportasi yang digunakan selama } 14 \\
\text { hari terakhir }\end{array}$ & & & \\
\hline & Mobil & 18 & $0(0 \%)$ & $0(0 \%)$ \\
\hline & Motor & 29 & $1(3,344 \%)$ & $2(6,89 \%)$ \\
\hline & Angkutan Umum & 3 & $0(\%)$ & $1(33,33 \%)$ \\
\hline \multirow[t]{3}{*}{8} & Beraktivitas di tempat ramai & & & \\
\hline & Ya & 7 & $0(0 \%)$ & $0(0 \%)$ \\
\hline & Tidak & 43 & $1(2,32 \%)$ & $3(6,97 \%)$ \\
\hline \multirow[t]{3}{*}{9} & Memakai masker & & & \\
\hline & Ya & 50 & $1(2 \%)$ & $3(6 \%)$ \\
\hline & Tidak & 0 & $0(0 \%)$ & $0(0 \%)$ \\
\hline \multirow[t]{3}{*}{10} & Jenis Masker & & & \\
\hline & Medis & 9 & $0(0 \%)$ & $0(0 \%)$ \\
\hline & Kain & 41 & $1(2 \%)$ & $3(6 \%)$ \\
\hline \multirow[t]{3}{*}{11} & Memakai faceshield & & & \\
\hline & Ya & 6 & $0(0 \%)$ & $0(0 \%)$ \\
\hline & Tidak & 44 & $1(2,27 \%)$ & $3(6,81 \%)$ \\
\hline
\end{tabular}

Keterangan:

*Anti SARS CoV-2

Melalui penelitian ini, dapat dilihat bahwa pemeriksaan cepat anti-SARS CoV-2 dengan menggunakan imunokromatografi merek Lungene kurang akurat, tetapi ada penelitian yang berpendapat lain. Ragnesola et al. (2020) menyatakan bahwa imunokromatografi merek Lungene merupakan alat deteksi COVID-19 yang sensitif dan spesifik untuk mendeteksi anti-SARS CoV-2 pada sampel donor plasma konvalesen. Hanya saja, pada penelitian tersebut tidak dilakukan perbandingan hasil dengan metode pengujian antibodi lain atau pemeriksaan konfirmasi dengan menggunakan qRT-PCR.

Terdapat beberapa penelitian yang membandingkan hasil pemeriksaan cepat anti-SARS CoV-2 dengan qRT-PCR dan semuanya melaporkan adanya hasil 
positif palsu dan negatif palsu (Choe et al., 2020; Jia et al., 2020; Shibata et al., 2020; Watson et al., 2020). Choe et al. (2020) melaporkan bahwa pemeriksaan antiSARS COV-2 dengan menggunakan imunokromatografi dapat menunjukkan hasil positif palsu dan negatif palsu.

Dari 70 orang yang terbukti terinfeksi SARS COV-2, pada pemeriksaan qRT-PCR hanya 65 orang mendapatkan hasil antiSARS COV-2 IgG/IgM reaktif. Dari 79 orang yang terbukti tidak terinfeksi SARS COV-2, pada pemeriksaan qRT-PCR hanya 76 orang mendapatkan hasil antiSARS COV-2 IgG/IgM non-reaktif. Hal ini membuktikan bahwa pada pemeriksaan tersebut terdapat hasil positif palsu sebesar 3,8\% dan negatif palsu sebesar $7,14 \%$ (Choe et al., 2020).

Shibata et al. (2020) juga melaporkan bahwa insidensi hasil positif palsu pada pemeriksaan antibodi IgG SARS CoV-2 cukup tinggi. Jumlah hasil positif palsu terhadap human common cold coronavirus adalah sebesar $57 \%$ dan pada virus lain, seperti influenza H1N1 serta rhinovirus mencapai $25 \%$. Hasil positif palsu dapat terjadi karena adanya reaksi silang antara antibodi human common cold coronavirus dan SARS CoV-2.

Selain itu, kehadiran Rheumatoid Factor (RF) dalam darah dapat menyebabkan hasil positif palsu pada pemeriksaan anti-SARS CoV-2 (Wang et al., 2020). RF adalah autoantibodi jenis IgM yang dapat mengenali segmen FC dari IgG yang didenaturasi. RF sudah sering kali dilaporkan menjadi faktor utama penyebab gangguan pada pemeriksaan berbasis serologi (Astarita et al., 2015; Kragstrup et al., 2013).

Hasil negatif palsu pada pemeriksaan cepat anti-SARS CoV-2 dapat terjadi karena, pada saat pemeriksaan dilakukan, antibodi belum terbentuk atau jumlahnya masih di bawah rentang deteksi kit imunokromatografi yang digunakan. Menurut Liu et al. (2020), IgG dan IgM SARS CoV-2 tidak dapat terdeteksi pada awal infeksi, yaitu hari pertama sampai ketiga.

Antibodi IgM mulai terdeteksi pada hari keempat, yang akan meningkat hingga mencapai puncak pada hari ke-20 dan selanjutnya mulai menurun. Antibodi IgG muncul pada hari ketujuh dan titernya mencapai puncak pada hari ke-25. Waktu pembentukan IgM dan IgG pada setiap orang sangat bervariasi tergantung usia dan komorbiditas (Liu et al., 2020).

Tuaillon et al. (2020) juga melaporkan bahwa metode imunokromatografi dapat mendeteksi antibodi SARS-CoV-2 pada $50 \%$ sampel yang dikumpulkan tujuh hari atau lebih setelah timbulnya gejala. Setelah 15 hari, tingkat deteksi meningkat menjadi lebih dari $80 \%$ tetapi tidak pernah mencapai $100 \%$. Oleh karena itu, pengujian antibodi sebaiknya dilakukan setidaknya dua minggu setelah timbulnya gejala (Tuaillon et al., 2020; Watson et al., 2020).

Selain hal tersebut, riwayat imunodefisiensi pasien dapat menjadi penyebab hasil negatif palsu pada pemeriksaan anti-SARS CoV-2 dan pemilihan gen untuk memproduksi antigen rekombinan yang digunakan produsen dalam imunokromatografi (Choe et al., 2020; Choy, 2020). Corman et al. (2020) melaporkan bahwa gen $\mathrm{N}$ menunjukkan sensitivitas yang lebih rendah dibandingkan dengan antigen $\mathrm{E}$ dan RdRp.

Pemeriksaan cepat anti-SARS CoV-2 dengan menggunakan imunokromatografi memang memiliki banyak keunggulan, antara lain waktu deteksi cepat, tidak membutuhkan peralatan khusus, cara pengerjaan dan interpretasi hasil yang sederhana, serta biaya pemeriksaan yang relatif terjangkau. Namun, metode tersebut juga memiliki beberapa keterbatasan, khususnya untuk mendiagnosis infeksi akut (Wang et al., 2020). Pemeriksaan cepat anti-SARS CoV2 lebih baik digunakan untuk mendiagnosis COVID-19 pada orang 
Hasil Positif Palsu dan Negatif Palsu pada Pemeriksaan Cepat...

dengan gejala yang berkepanjangan atau mendapatkan hasil negatif pada pemeriksaan qRT-PCR (Watson et al., 2020).

\section{PENUTUP}

Pemeriksaan cepat anti-SARS CoV-2 yang dilakukan di Kecamatan Cimahi Tengah menunjukkan hasil yang kurang akurat. Hal ini dibuktikan dengan adanya hasil positif palsu pada empat orang (8\%) dan negatif palsu pada satu orang (2\%) sampel penelitian.

Oleh sebab itu, masyarakat yang dinyatakan anti-SARS CoV-2 IgM dan IgG non-reaktif disarankan untuk melakukan protokol kesehatan. Adapun protokol kesehatan yang dimaksud, di antaranya, menggunakan masker, rajin mencuci tangan, dan selalu menjaga jarak dengan orang lain.

Sebaliknya, masyarakat yang mendapatkan hasil anti-SARS CoV-2 IgG/ IgM reaktif disarankan untuk melakukan pemeriksaan konfirmasi dengan menggunakan metode qRT-PCR. Selama menunggu hasil pemeriksaan, masyarakat diharapkan untuk melakukan isolasi mandiri di dalam rumah. Melalui penelitian ini juga diharapkan pemerintah dapat meninjau kembali metode pemeriksaan serologis yang dapat digunakan untuk mendeteksi penyakit COVID-19 secara cepat.

\section{UCAPAN TERIMA KASIH}

Terima kasih kepada LPPM Stikes Jenderal Achmad Yani atas dana penelitian yang telah diberikan serta kepada Satgas Penanganan dan Pencegahan COVID-19 Stikes Jenderal Achmad Yani atas bantuan berupa data hasil pemeriksaan COVID-19 menggunakan metode qRT-PCR.

\section{DAFTAR PUSTAKA}

Astarita, G., Gutiérrez, S., Kogovsek, N., Mormandi, E., Otero, P., Calabrese, C., Alcaraz, G., Vázquez, A., \&
Abalovich, M. (2015). False positive in the measurement of thyroglobulin induced by rheumatoid factor. Clinica Chimica Acta, 447, 43-46. https:// doi.org/10.1016/j.cca.2015.04.039

Choe, J., Kim, J., Kwon, H. H., Hong, H., Jung, C. Y., Jeon, C., Park, E., \& Kim, S. (2020). Diagnostic performance of immunochromatography assay for rapid detection of $\operatorname{IgM}$ and IgG in coronavirus disease 2019. Journal of Medical Virology, 92(11), 2567-2572. https://doi.org/10.1002/jmv.26060

Choy, K. W. (2020). Specificity and crossreactivity of a test for anti-SARS-CoV2 antibodies. The Lancet. Infectious Diseases. $\quad$ https://doi.org/10.1016/ S1473-3099(20)30787-8

Corman, V. M., Landt, O., Kaiser, M., Molenkamp, R., Meijer, A., Chu, D. K., Bleicker, T., Brünink, S., Schneider, J., Schmidt, M. L., Mulders, D. G., Haagmans, B. L., van der Veer, B., van den Brink, S., Wijsman, L., Goderski, G., Romette, J.-L., Ellis, J., Zambon, M., ... Drosten, C. (2020). Detection of 2019 novel coronavirus (2019-nCoV) by real-time RT-PCR. Eurosurveillance, 25(3). https://doi.org/10.2807/15607917.ES.2020.25.3.2000045

Handayani, D., Hadi, D. R., Isbaniah, F., Burhan, E., \& Agustin, H. (2020). Corona Virus Disease 2019. Jurnal Respirologi Indonesia, 40(2). https:// doi.org/10.36497/jri.v40i2.101

Huang, C., Wang, Y., Li, X., Ren, L., Zhao, J., Hu, Y., Zhang, L., Fan, G., Xu, J., Gu, X., Cheng, Z., Yu, T., Xia, J., Wei, Y., Wu, W., Xie, X., Yin, W., Li, H., Liu, M., ... Cao, B. (2020). Clinical features of patients infected with 2019 novel coronavirus in Wuhan, China. The Lancet, 395(10223), 497-506. https:// doi.org/10.1016/S0140-6736(20)30183-5

Jia, X., Xiao, L., \& Liu, Y. (2020). False negative RT-PCR and false positive antibody tests-Concern and solutions in the diagnosis of COVID-19. The Journal of Infection. https://doi.org/ 
10.1016/j.jinf.2020.10.007

Kemenkes RI. (2020a). COVID-19 dalam Angka. Kemkes.Go.Id. https:// www.kemkes.go.id/folder/view/01/ structure-info-terkini.html

Kemenkes RI. (2020b). Pedoman Pencegahan dan Pengendalian Coronavirus Disease (COVID-19). (L. Aziza, A. Aqmarina, \& M. Ihsan (eds.)). Kementerian Kesehatan RI. https:// infeksiemerging.kemkes.go.id/

download/REV-

05_Pedoman_P2_COVID-

19_13_Juli_2020_1.pdf

Kragstrup, T. W., Vorup-Jensen, T., Deleuran, B., \& Hvid, M. (2013). A simple set of validation steps identifies and removes false results in a sandwich enzyme-linked immunosorbent assay caused by antianimal IgG antibodies in plasma from arthritis patients. SpringerPlus, 2(1), 263. https://doi.org/10.1186/2193-18012-263

Liu, X., Wang, J., Xu, X., Liao, G., Chen, Y., \& Hu, C.-H. (2020). Patterns of IgG and IgM antibody response in COVID-19 patients. Emerging Microbes $\mathcal{E}$ Infections, 9(1), 1269-1274. https:// doi.org/ 10.1080/22221751.2020.1773324

Lu, R., Zhao, X., Li, J., Niu, P., Yang, B., Wu, H., Wang, W., Song, H., Huang, B., Zhu, N., Bi, Y., Ma, X., Zhan, F., Wang, L., Hu, T., Zhou, H., Hu, Z., Zhou, W., Zhao, L., ... Tan, W. (2020). Genomic characterisation and epidemiology of 2019 novel coronavirus: implications for virus origins and receptor binding. The Lancet, 395(10224), 565-574. https:// doi.org/10.1016/S0140-6736(20)30251-8

Okba, N. M. A., Müller, M. A., Li, W., Wang, C., Geurts van Kessel, C. H., Corman, V. M., Lamers, M. M., Sikkema, R. S., de Bruin, E., Chandler, F. D., Yazdanpanah, Y., Le Hingrat, Q., Descamps, D., Houhou-Fidouh, N., Reusken, C. B. E. M., Bosch, B.-J.,
Drosten, C., Koopmans, M. P. G., \& Haagmans, B. L. (2020). Severe Acute Respiratory Syndrome Coronavirus 2-Specific Antibody Responses in Coronavirus Disease Patients. Emerging Infectious Diseases, 26(7), 1478-1488. https://doi.org/10.3201/ eid2607.200841

Pemda Cimahi. (2020). Infografik COVID19 Kota Cimahi. PICC: Pusat Informasi Covid-19 Cimahi. https:// covid19.cimahikota.go.id/infografik

Ragnesola, B., Jin, D., Lamb, C. C., Shaz, B. H., Hillyer, C. D., \& Luchsinger, L. L. (2020). COVID19 antibody detection using lateral flow assay tests in a cohort of convalescent plasma donors. BMC Research Notes, 13(1), 372. https:// doi.org/10.1186/s13104-020-05212-0

Rothan, H. A., \& Byrareddy, S. N. (2020). The epidemiology and pathogenesis of coronavirus disease (COVID-19) outbreak. Journal of Autoimmunity, 109, 102433. https://doi.org/10.1016/ j.jaut.2020.102433

Shibata, S., Ishiguro, T., Kobayashi, Y., Koike, M., Numano, T., Shimizu, Y., \& Takayanagi, N. (2020). High incidence of false-positive results of $\mathrm{IgG}$ antibody against SARS-CoV-2 with rapid immunochromatographic antibody test due to human common cold coronavirus infection. Respiratory Medicine Case Reports, 31, 101180. https://doi.org/10.1016/j.rmcr. 2020.101180

Susilo, A., Rumende, C. M., Pitoyo, C. W., Santoso, W. D., Yulianti, M., Herikurniawan, H., Sinto, R., Singh, G., Nainggolan, L., Nelwan, E. J., Chen, L. K., Widhani, A., Wijaya, E., Wicaksana, B., Maksum, M., Annisa, F., Jasirwan, C. O. M., \& Yunihastuti, E. (2020). Coronavirus Disease 2019: Tinjauan Literatur Terkini. Jurnal Penyakit Dalam Indonesia, 7(1), 45. https://doi.org/10.7454/jpdi.v7i1.415

Tuaillon, E., Bolloré, K., Pisoni, A., Debiesse, S., Renault, C., Marie, S., 
Groc, S., Niels, C., Pansu, N., Dupuy, A., Morquin, D., Foulongne, V., Bourdin, A., Le Moing, V., \& Van de Perre, P. (2020). Detection of SARSCoV-2 antibodies using commercial assays and seroconversion patterns in hospitalized patients. Journal of Infection, 81(2), e39-e45. https:// doi.org/10.1016/j.jinf.2020.05.077

van Doremalen, N., Bushmaker, T., Morris, D. H., Holbrook, M. G., Gamble, A., Williamson, B. N., Tamin, A., Harcourt, J. L., Thornburg, N. J., Gerber, S. I., Lloyd-Smith, J. O., de Wit, E., \& Munster, V. J. (2020). Aerosol and Surface Stability of SARS-CoV-2 as Compared with SARS-CoV-1. New England Journal of Medicine, 382(16), 1564-1567. https:// doi.org/10.1056/NEJMc2004973

Wang, Q., Du, Q., Guo, B., Mu, D., Lu, X., Ma, Q., Guo, Y., Fang, L., Zhang, B., Zhang, G., \& Guo, X. (2020). A Method To Prevent SARS-CoV-2 IgM False Positives in Gold
Immunochromatography and Enzyme-Linked Immunosorbent Assays. Journal of Clinical Microbiology, 58(6). https://doi.org/10.1128/JCM. 00375-20

Watson, J., Richter, A., \& Deeks, J. (2020). Testing for SARS-CoV-2 antibodies. BMJ, m3325. https://doi.org/10.1136/ bmj.m3325

WHO. (2020). Coronavirus disease (COVID19): Situation Report, 198. https:// apps.who.int/iris/bitstream/handle/ 10665/333735/nCoVsitrep05Aug2020eng.pdf?sequence $=1 \&$ is Allowed $=y$ Zhou, P., Yang, X.-L., Wang, X.-G., Hu, B., Zhang, L., Zhang, W., Si, H.-R., Zhu, Y., Li, B., Huang, C.-L., Chen, H.-D., Chen, J., Luo, Y., Guo, H., Jiang, R.-D., Liu, M.-Q., Chen, Y., Shen, X.-R., Wang, X., ... Shi, Z.-L. (2020). A pneumonia outbreak associated with a new coronavirus of probable bat origin. Nature, 579(7798), 270-273. https://doi.org/10.1038/s41586-0202012-7 